\title{
Influence of temperature on microsporidia infections in a natural population of Simulium pertinax Kollar, 1832 (Diptera; Simuliidae)
}

\author{
Nascimento, ES. ${ }^{\mathrm{a} b *}$, Figueiró, R. ${ }^{\mathrm{a}}$, Becnel, JJ. ${ }^{\mathrm{c}}$ and Araújo-Coutinho, CJPC.$^{\mathrm{a}, \mathrm{d}}$ \\ aLaboratório de Referência Nacional em Simulídeos e Oncocercose, Departamento de Entomologia, \\ Instituto Oswaldo Cruz - FIOCRUZ, CP 926, CEP 21045-900, Rio de Janeiro, RJ, Brazil \\ bPrograma de Pós Graduação em Biologia Animal, Universidade Federal Rural do Rio de Janeiro - UFRRJ, \\ CEP 23890-000, Seropédica, RJ, Brazil \\ 'US Department of Agriculture Agricultural research Service, P.O. Box 14565, Gainesville, FL, USA \\ ${ }^{\mathrm{d}}$ Visiting researcher FIOCRUZ / SUCEN \\ *e-mail: erikar@ioc.fiocruz.br
}

Received July 12, 2005 - Accepted May 22, 2006 - Distributed August 31, 2007

(With 9 figures)

\begin{abstract}
During the studies involving the correlation between the water temperature of the breeding site of Simulium pertinax larvae and the infection prevalence by microsporidia, developed in the Andorinhas river, Magé, RJ, weekly samples of blackfly larvae were taken within a two-year period (2001-2002 and 2003-2004), and it was noticed that the infections by Amblyospora sp. were more prevalent when compared to infections by Polydispyrenia sp. in larvae. It was also observed that the infections do not follow the same pattern, since the genus Amblyospora was recorded almost every month during the study with the exception of December, 2001. In the results of correlation between the environmental water temperature and the microsporidia infection rates, it was observed that for the first period studied, there was a high negative correlation, while during the second period there was absence correlation. On the other hand, the Amblyospora sp. infection rates prove that the correlation was high and significant in the first period, but was not significant in the second sampling period and Polydispyrenia sp. showed absence correlation in both periods.
\end{abstract}

Keywords: entomopathogenic protozoan, biological control, temperature, Simuliidae, microsporidia.

\section{Influência da temperatura nas infecções por microsporídeos em população natural de Simulium pertinax (Diptera; Simuliidae)}

\begin{abstract}
Resumo
Este estudo envolvendo a correlação entre a temperatura da água do criadouro de larvas de Simulium pertinax e a prevalência de infecção por microsporídeos, foi desenvolvido no rio Andorinhas, Magé, RJ, onde foram realizadas coletas semanais de larvas de simulídeos no período de dois anos (2001-2002 e 2003-2004), e foi observado que as infecções por Amblyospora sp. apresentaram maior prevalência quando comparadas com as infecções por Polydispyrenia sp. Com isso, verificou-se que as infecções não seguem o mesmo padrão, onde o gênero Amblyospora foi relatado em quase todos os meses de desenvolvimento do estudo, com exceção apenas de dezembro de 2001. Nos resultados de correlação entre a temperatura ambiente e a taxa de infecção por microsporídeos no primeiro período de estudo, foi observada uma forte correlação negativa, porém foi verificada ausência de correlação no segundo período. Embora tenha sido evidenciada uma forte e significante correlação com a taxa de infecção por Amblyospora sp. no primeiro período, esta correlação mostrou-se não significativa no segundo período de amostragem e Polydispyrenia sp. apresentou ausência de correlação em ambos os períodos de estudo.
\end{abstract}

Palavras-chave: protozoário entomopatogênico, controle biológico, temperatura, Simuliidae, microsporídeos. 


\section{Introduction}

The importance of family Simuliidae for human health lies in the fact that the females of certain species within the genus Simulium Latreille, 1802 are vectors of Onchocerca volvulus (Leuckart, 1893) Railliet and Heney, 1910 (Nematoda: Onchocercidae), a filarid that causes human onchocerciasis, found in the Neotropical Americas and Western and Central Africa (Shelley, 2002). In Brazil, the onchocerciasis was reported in the northern part of the state of Roraima by Moraes and Chaves (1974); in northern Goiás, where the first autochthonous case outside of the Amazonian region was reported (Gerais and Ribeiro, 1986), and more recently, it was described in northern Amazonas (Shelley et al., 1997). In south and southeastern Brazil, where there is no Onchocerciasis transmission, the importance of Simuliidae is related to the high biting rates, in regions where the populations of anthropophilic species show high densities.

Among the aforementioned species, there is Simulium pertinax Kollar, 1832, which has records in Argentina, Brazil and Paraguay (Coscarón, 1987), and is considered a plague in various regions in Brazil, which has been target of many control efforts in the last decades (Campos and Andrade, 2001). Due to the dispersal characteristics of the adults, the larvicide control has been the main method applied to the control of these organisms.

When using biological control, pathogens with efficient transmission and moderated virulence can be the more effective (Maddox, 1987). In this context, the microsporidia are organisms that show better potential as long term agents (Sweeney and Becnel, 1991).

The few studies found in the literature approaching the relationship between microsporidia and simuliids under the influence of temperature are restricted to Culiciidae, and are laboratorial studies within controlled temperature (Undeen et al., 1993).

This reinforces the need for the evaluation of the influence of temperature on the Simuliidae (Diptera), especially in Brazil, where the studies that involve the hostparasite relationship approach only the seasonality and the determination of the occurrence of entomopathogens on larval populations (Araújo-Coutinho et al., 2004).

The importance of the present study lies in the acquisition of information that will help further studies on the biology and ecology of microsporidia found in Brazil, which will help the establishment of determinant parameters of the host-parasite relationship, as well as the enzootics and epizootics, allowing the utilization of this pathogen as part of a blackfly integrated management program.

The aim of this study was to evaluate the correlation between the water temperature of the breeding site and the prevalence of Amblyospora sp. (Microsporidia: Amblyosporidae) and Polydispyrenia sp. (Microsporidia: Duboscqiidae) in the population of Simulium pertinax (Diptera: Simuliidae).

\section{Material and Methods}

This study was carried out in a two non-consecutive year period with weekly samples (May 2001 to 2002 and May 2003 to 2004) in the Andorinhas river, municipality of Magé, Rio de Janeiro state ( $22^{\circ} 32^{\prime} \mathrm{S}$ and $43^{\circ} 02^{\prime} \mathrm{W}$ ), $88 \mathrm{~m}$ high, mean pluviosity between 1250 and $1500 \mathrm{~mm}$ a year. This river shows a wide insolation surface, with predominantly rocky substrate and it is a considerable high drainage river (Figures 1a, b). Its riparian vegetation consists of degraded Atlantic forest, a consequence of urbanization brought by industrialisation in Magé in the 30 's.

The data on the mean maximum and minimum temperature and the pluviometric precipitation were obtained in the National Institute of Meterology, Rio de Janeiro and were examined with the objective of establishing if these two years were atypical. The water temperature was measured in all samplings using a digital thermometer.

Due to the need of in vivo observation of the external symptomatology of the protozoan infection, the larvae were immediately transported to the laboratory in recipients where the larvae were provided with water from their original breeding site, as well as aeration from pumps suitable for aquariums. The $S$. pertinax larvae that showed the infection symptoms as deformed abdomen, fat bodies whitened and in globular form (Figure 2), were dissected and stained according to Becnel (1997). The protozoans were identified in a light phase microscope, using the identification key proposed by Weiser (1991).
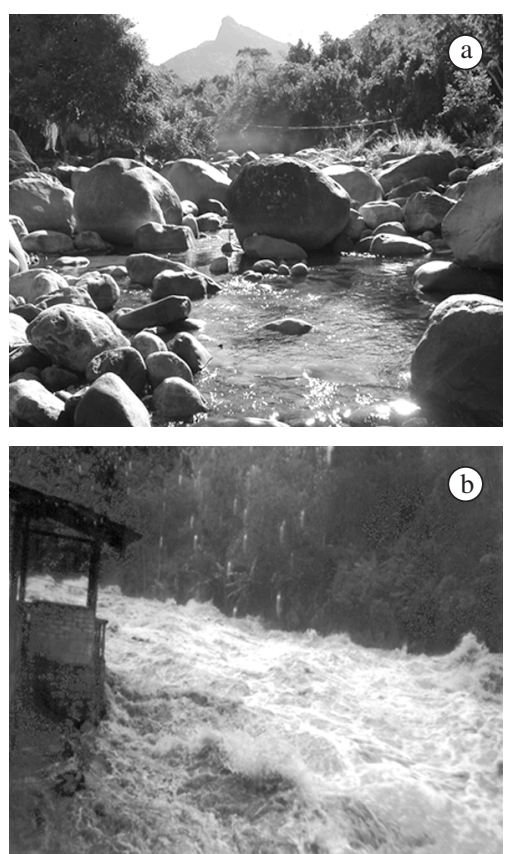

Figure 1. a) Andorinhas river, Magé Municipality; and b) Periods that showed a high drainage river sometimes in the humid season, October to April. 
The seasonal profile of the microsporidia was established from the relative frequencies of the genera, where the percentage values of $S$. pertinax larvae were calculated for the following situations: percentage of infected specimens in relation to the absolute total; percentage of infected specimens in relation to the monthly total; percentage of microsporidia genera found in relation to the absolute total of the infected specimens.

Based on this evaluation, the Sorensen similarity test was applied on weekly infection data in order to observe the incidence pattern of the infection.

Due to the coexistence of more than one microsporidia genus infecting S. pertinax in the river where the present study was held, the Fager affinity index (1957) at $1 \%$ error was applied, which is of great use when recognizing real interspecific association.

The linear correlation between the water temperature and the microsporidia infections in the Andorinhas river was estimated by applying the Pearson coefficient, applied to the total infected larvae per sampling period, as well as for the total infected larvae per microsporidia genus. The " $t$ " test at 5\% was carried out in order to observe the significance of the correlation data. In order to determine if the correlation should be accepted or not, the Rugg Table was used as a parameter (Serra-Freire, 2002).

The total prevalence was calculated to the total amount of S. pertinax infected larvae, and for the larvae infected by the microsporidia genera detected in the 77 weeks involved in this research, with the objective of estimating the annual infection profile.

In order to verify if the sample size influences the correlation between the water temperature and the microsporidia infections in $S$. pertinax, the Pearson linear correlation coefficient was applied on the prevalence of the total larvae sampled, on the monthly prevalence of infected larvae per microsporidia genus in both periods studied (2001-2002 and 2003-2004).

Pearson was also applied to the monthly data of pluviometric precipitation, in the periods 2001-2002 and

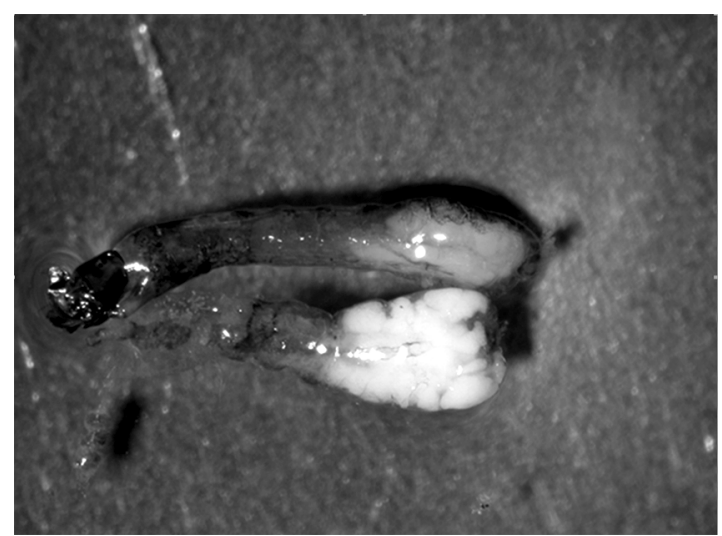

Figure 2. Simulium pertinax larvae infected with microsporidia.
2003-2004, on the monthly data of water temperature, total sampled larvae and infected larvae.

\section{Results}

The first year of study had a mean water temperature of $21.74{ }^{\circ} \mathrm{C}$, which varied from $19.60{ }^{\circ} \mathrm{C}$ (September) to $24.95{ }^{\circ} \mathrm{C}$ (December). The second period had a mean water temperature of $21.23{ }^{\circ} \mathrm{C}$, floating between $18.90{ }^{\circ} \mathrm{C}$ (August) and $23.40{ }^{\circ} \mathrm{C}$ (January) (Figure 3). The pluviometric precipitation varied between $2.3 \mathrm{~mm}$ (June) and $422.2 \mathrm{~mm}$ (December) in the first year, and $31.6 \mathrm{~mm}$ (June) and $351.1 \mathrm{~mm}$ (November) in the second year (Figure 4). This data showed that this year was not atypical, when compared to the last decade time series.

The microsporidia genera Amblyospora (Hazard and Oldacre, 1975) and Polydispyrenia (Canning and Hazard, 1982), which were found to be infecting the fat tissue of S. pertinax larvae, were identified based on morphological characteristics of the spore (Figures 5a, b).

During 2001-2002, a total of 10,603 S. pertinax larvae were sampled, and 207 infected larvae detected, from which 201 were infected by the genus Amblyospora and 6 larvae were infected by genus Polydispyrenia. Amblyospora sp. showed relative frequency of $1.90 \%$ in

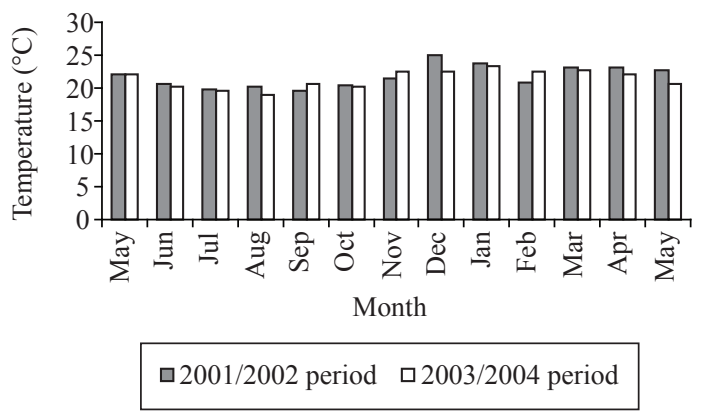

Figure 3. The mean of water temperature from the Andorinhas river in two periods.



Figure 4. The pluviometric precipitation in the Andorinhas river, Magé Municipality. 
the S. pertinax larval population, representing $97.10 \%$ of the microsporidia detected. Polydispyrenia sp. had a relative frequency of 0.06 , which stands for just $2.90 \%$ of the microsporidia found.

Amblyospora sp. occurred in all the studied period, except for December 2001, and was registered with a bigger prevalence from June to August, and in October 2001, and the infection peaks can be observed in June $(1.95 \%)$, July $(3.88 \%)$, August $(2.60 \%)$ and October (3.30\%). However, this was not true for Polydispyrenia sp., which occurred only in October 2001, February and May 2002, showing a low prevalence (Figure 6).

In the period between 2003 - 2004, 24,116 S. pertinax larvae were sampled, 396 of these were infected by the genus Amblyospora and 42 infected by the genus Polydispyrenia. Amblyospora sp. Showed a relative frequency of $1.64 \%$ in the $S$. pertinax larvae population, which stood for $90.40 \%$ of the microsporidia found. Polydispyrenia sp. had $0.17 \%$ relative frequency in the population, representing $9.60 \%$ of the detected microsporidia.

As it happened in the first year of study, Amblyospora sp. infections were reported throughout the whole period, but in this case, the infection peaks occurred from July to October 2003 and from March to May 2004. These epizootics represented a prevalence of $1.36 \%$ in July, $1.13 \%$ in August, 2.43\% in September and 4.08\% in October 2003; and in 2004 the most representative
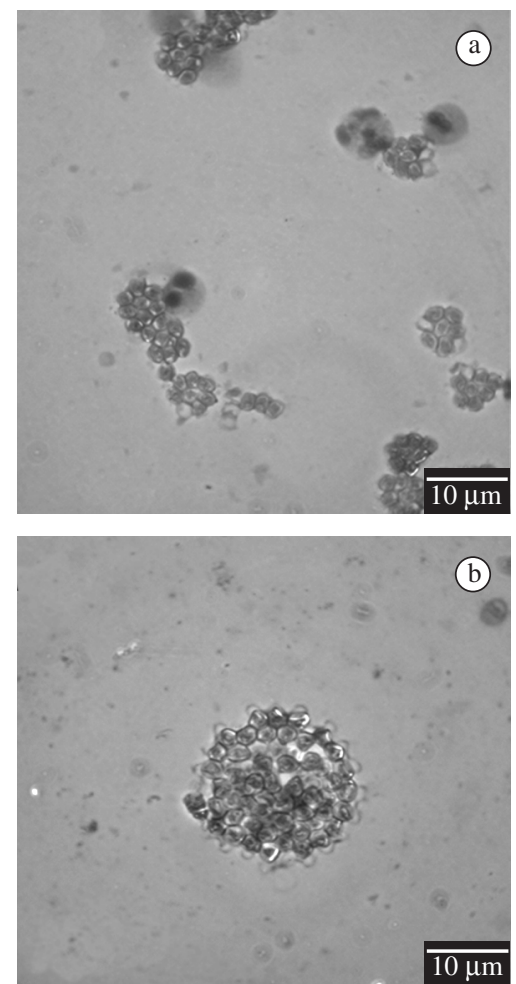

Figure 5. a) Amblyospora sp. spores and b) Mature Polydispyrenia sp. Cysts, isolated from S. pertinax collected in the Andorinhas river. prevalences were in March (1.05\%), April (1.24\%) and May $(2.44 \%)$. However, Polydispyrenia sp. occurred throughout almost the whole period except in May 2003 and February 2004, showing a low prevalence in all the study period (Figure 7).

According to these patterns, low parasitary similarity was achieved (59.34\%), which means that the infections do not follow the same pattern. According to the affinity index, it was observed that Tcalc $=15.4540>$ Ttab $1 \%=3.91$. This leads to the conclusion that Amblyospora sp. and Polydispyrenia sp. infections in S. pertinax larvae are not influenced by one another.

The correlation between the total $S$. pertinax infected larvae and water temperature, in the studied periods, was negative $(\mathrm{r}=-0.52$ com $\mathrm{p}<0.05)$. The correlation between the water temperature and the Amblyospora sp. infections in the period 2001-2002 was negative $(r=-0.65$ com $p<0.05)$ and considered strong throughout 2003-2004. A negative correlation was also recorded $(\mathrm{r}=-0.43$, com $\mathrm{p}<0.05)$. Polydispyrenia $\mathrm{sp}$. showed no significant correlation $(\mathrm{r}=-0.10 \mathrm{com} \mathrm{p}<0.05)$ in the

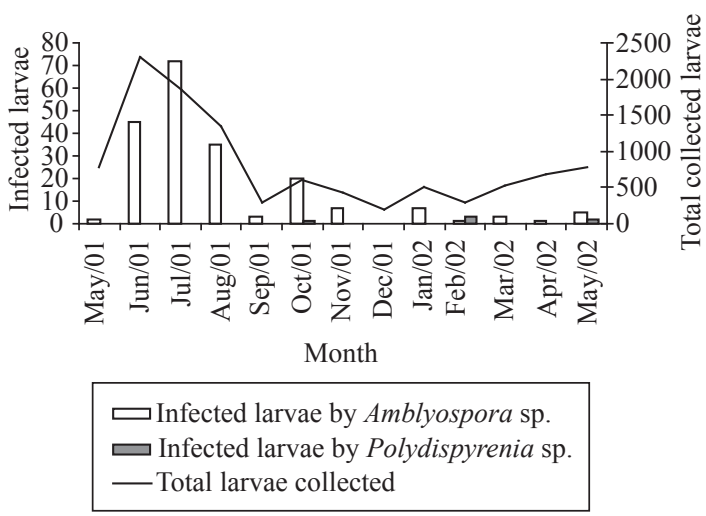

Figure 6. Seasonal occurrence of Amblyospora sp. and Polydispyrenia sp. collected in the Andorinhas river, Magé Municipality between $2001-2002$.

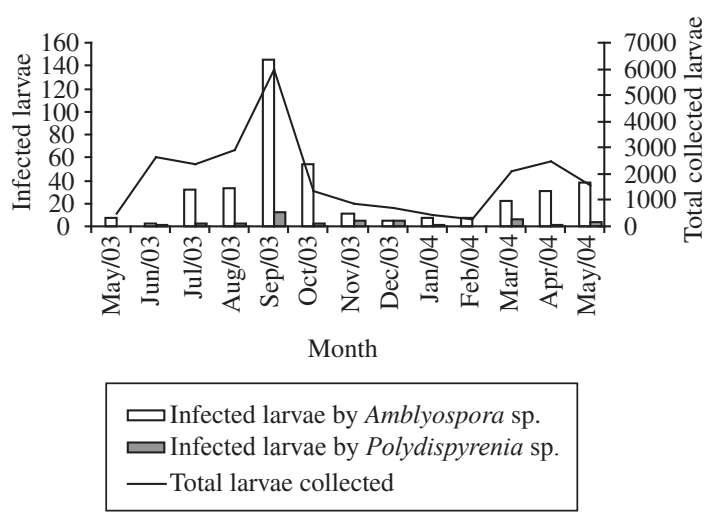

Figure 7. Seasonal occurrence of Amblyospora sp. and Polydispyrenia sp. collected in the Andorinhas river, Magé Municipality between 2003-2004. 
2001-2001 period, nor in the 2003-2004 period $(r=0.10$ com $\mathrm{p}<0.05)$.

To diminish the possible influence of the sample size in the correlation, an infection rate for the 77 weeks involved in the study was used, which was $1.86 \%$ for S. pertinax larvae infections by microsporidia, $1.72 \%$ for the genus Amblyospora and $0.14 \%$ for the genus Polydispyrenia (Table 1).

The first studied period had no significant correlation between the water temperature and the infection rate on the total $S$. pertinax larvae sampled $(r=-0.45$; $\mathrm{p}<0.05)$. On the other hand, the negative correlation between the water temperature and the infection rate of the infected larvae was strong $(\mathrm{r}=-0.69$ com $\mathrm{p}<0.05)$; and for Amblyospora sp. Infections, a strong negative correlation $(\mathrm{r}=-0.64$ com $\mathrm{p}<0.05)$ was observed while a correlation for Polydispyrenia sp. infections $(\mathrm{r}=-0.17$ com $\mathrm{p}<0.05$ ) was not observed (Figure 8).

For the pluviometrical precipitation within the 20012002 period, the following correlations were obtained: a strong correlation with the temperature $(r=0.76 \mathrm{com}$ $\mathrm{p}<0.05)$; a strong negative correlation with the infection rate of the total sampled larvae $(\mathrm{r}=-0.66 ; \mathrm{p}<0.05)$; a non significant correlation with the total infected larvae infection rate $(r=-0.48 ; \mathrm{p}<0.05)$; a strong negative correlation with the infection rate of Amblyospora sp. infected larvae $(r=-0.68 ; \mathrm{p}<0.05)$ and an absence of the significant correlation with the infection rate of Polydispyrenia sp. infected larvae $(\mathrm{r}=0.11 ; \mathrm{p}<0.05)$.

During the second period, the correlation between the water temperature and infection rate of sampled larvae was not significant $(\mathrm{r}=-0.54 ; \mathrm{p}<0.05)$. There was no significant correlation between the water temperature and the infection rate of infected larvae $(\mathrm{r}=-0.01$; p < 0.05); and the same was true for the Amblyospora sp. infections $(r=-0.09$ com $\mathrm{p}<0.05)$ and for the Polydispyrenia sp. infections $(\mathrm{r}=0.37$ com $\mathrm{p}<0.05)$ where the correlation with the water temperature was not significant (Figure 9).

For the pluviometrical precipitation within the 20032004 period, the following correlations were obtained: a strong correlation with the water temperature $(r=0.65$; $\mathrm{p}<0.05)$; a strong negative correlation with the infection rate of total sampled larvae $(\mathrm{r}=-0.58 ; \mathrm{p}<0.05)$; a non significant correlation with the infection rate of the total infected larvae $(\mathrm{r}=0.31 ; \mathrm{p}<0.05)$; a non significant correlation with the Amblyospora sp. infected larvae $(\mathrm{r}=-0.20 ; \mathrm{p}<0.05)$; and a non significant correlation

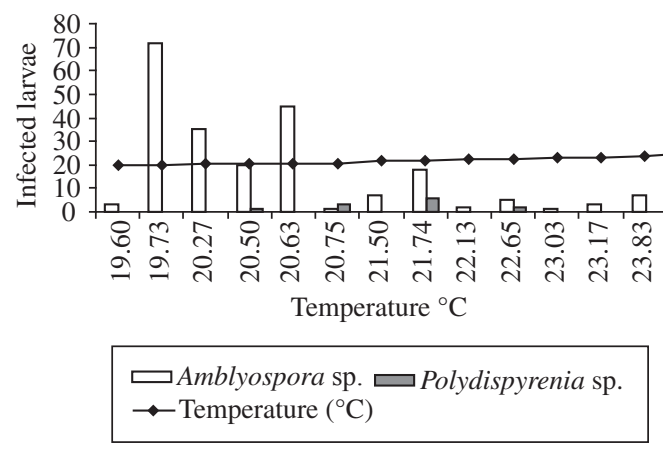

Figure 8. The Amblyospora sp. and Polydispyrenia sp. abundance with a mean of temperature variety between 2001-2002.

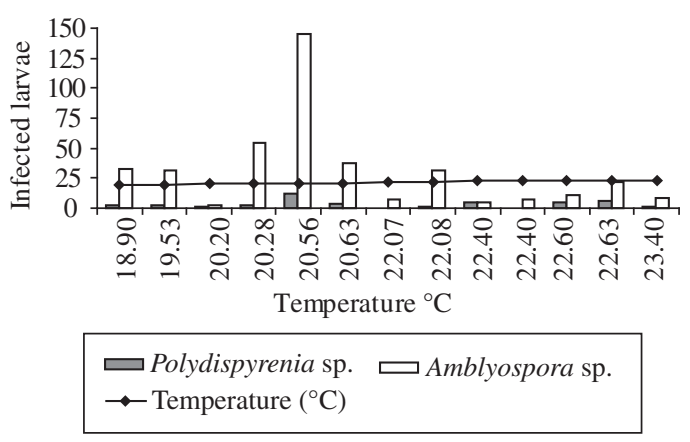

Figure 9. The Amblyospora sp. and Polydispyrenia sp. abundance with a mean of temperature variety between 2003-2004.

Table 1. Infected larvae by microsporidia genera percentage that was found in two periods (2001-2002 / 2003-2004) with relation to the water temperature $\left({ }^{\circ} \mathrm{C}\right)$ variation in the Andorinhas river.

\begin{tabular}{cccccccc}
\hline Temperature & Amblyospora & Polydispyrenia & TLI & TLC & P A (\%) & P P (\%) & PTLI (\%) \\
\hline $17.0 \mid-19.0$ & 108 & 4 & 112 & 6043 & 1.79 & 0.07 & 1.85 \\
$19.0 \mid-21.0$ & 113 & 12 & 125 & 8991 & 1.26 & 0.13 & 1.39 \\
$21.0 \mid-23.0$ & 303 & 20 & 323 & 13858 & 2.19 & 0.14 & 2.33 \\
$23.0 \mid-25.0$ & 71 & 12 & 83 & 5417 & 1.31 & 0.22 & 1.53 \\
$25.0 \mid-27.0$ & 2 & 0 & 2 & 451 & 0.44 & 0.00 & 0.44 \\
$\Sigma$ & 597 & 48 & 645 & 34719 & 1.72 & 0.14 & 1.86 \\
\hline
\end{tabular}

TLI - Total of infected Simulium pertinax larvaeTLC - Total of sample Simulium pertinax larvae;

P A - Percentage of infected Simulium pertinax larvae by Amblyospora sp.;

P P - Percentage of infected Simulium pertinax larvae by Polydispyrenia sp.;

PTLI - Percentage of total infected Simulium pertinax larvae. 
with the infection rate of Polydispyrenia sp. infected larvae $(r=0.20 \mathrm{com} p<0.05)$. The data was interpreted according to Rugg's table.

\section{Discussion}

Even though the microsporidia identified was based on the morphological parameters and measuring of spores, it was only possible up to the genus level, where the two genera Amblyospora sp. and Polydispyrenia sp. were found. It was stated that identifying the species was not possible with only morphological characteristics, because the spores of Polydispyrenia sp. showed differences in the spore dimensions when compared to the dimensions of the spore type species identified in parasiting blackflies in Brazil (Polydispyrenia simulii), and for genera Amblyospora sp. the spores showed Amblyospora bracteata and Amblyospora varians identified from South America and Europe. Therefore, this could not be the only criterion used, and the molecular characterization was made necessary, in addition to the morphological characterization.

The seasonal variation of $S$. pertinax abundance did not follow the pattern described in the literature, in which the population usually rises from October to April (humid season) (Araújo-Coutinho, 1993). The opposite was observed in the Andorinhas river, a high drainage river, in which it can be observed that the host population rose from June to October (dry season). According to Peterson (1956), the Simuliidae populations are influenced by water velocity and are directly related with catching food and falency of the cephalic fan (morphological structures). Probably this factor can be analyzed as a determining factor for the larvae abundance.

The dominant microsporidia genus was Amblyospora, showing enzootics in the two studied years, persisting even when the host population was reduced. This was also reported by Andreadis (1999) in a study developed with a natural population of Culicidae. During the 20012002 year period, enzootic peaks were registered from June to August and in October 2001; and the incidence of these epizootics behaved in a different way in the 20032004 period, which happened from July to October 2003 and from March to May 2004. This information made it possible to observe that Amblyospora sp. shows a chronic infection in the $S$. pertinax population, even though a few epizootics could be observed. Micieli et al. (2001) studied a natural population of Aedes albifasciatus (Diptera: Culicidae), and reported an enzootic pattern of Amblyospora albifasciati similar to the one found in this present study, and the enzootic peaks occurred approximately in the same months as the ones observed in this study (June to October).

The opposite of what happens with Amblyospora sp., happened with the genus Polydispyrenia and was not pro-eminent in the first period of study, representing only $0.06 \%$ of the $S$. pertinax population and found only in three months (October, February and May). In the sec- ond period, the infection rate was $0.17 \%$ and a consistent temporal distribution was found in almost all the studied period, except for May and February.

Amblyospora sp. and Polydispyrenia sp. infections have been reported in various South American blackfly species (Garcia et al., 1989), though not much is known about their enzootic and epizootic aspects, as well as the key factors that act on the microsporidiosis in host populations in these systems.

Despite progress in the knowledge of transmission and biology aspects of Amblyospora in natural populations, there are no reports in blackflies, and for this reason, some results were discussed comparing with existing data related to a different host.

The microsporidia infection ratio in $S$. pertinax larvae was $1.86 \%$, where $1.72 \%$ of this value were Amblyospora sp. infections and $0.14 \%$ Polydispyrenia sp. This report is similar to the ones from other studies on Simuliidae, in which the infection rate can vary from 0.5 to $2.5 \%$, and more often, the rate is lower than $1 \%$ (Crosskey, 1990).

The main reason as to why the spore size of Amblyospora sp. described in the present study is different may be the influence of abiotic factors such as the temperature. The spore size and shape are important taxonomic characteristics used to distinguish species of microsporidia. Some studies have found that spore sizes of one species is not affected by the host type (Thomson, 1960) or the temperature at which the host is reared (Jouvenaz and Lofgren, 1984). Other studies, however, have shown that the spore size of a given species can vary significantly depending on the host type (Brooks and Cranford, 1972), the stage of the host (Thomson, 1960), and the temperature at which the infected host is reared (Sedlacek et al., 1985). Even though there was no significant variation in the water temperature of the Andorinhas river, this abiotic factor may have influenced the spore size.

Even though there was a negative correlation between Amblyospora sp. and the water temperature, the same analysis was performed using the infection rates instead of the absolute numbers with the objective of observing if the sample size influenced the result. There was a correlation between the water temperature and the infection rates only in the first period and with the genera Amblyospora, so probably another factor influenced the infections by Amblyospora in this river. Furthermore, the correlation analysis applied to the pluviometrical precipitation, and only in the first period was there a strong correlation for Amblyospora sp. This means that neither the water temperature nor the precipitation influenced the infection rate. Then it is acceptable to say that the infection rates do not show a correlation with the abiotic factors in the Andorinhas river due to the fact that it is a high drainage breeding site, where the host behaviour is different from that observed in normal drainage breeding sites, in addition to the little variation between the maximum and minimum temperatures, that were within 
an optimal range for microsporidia infections (Undeen et al., 1993).

However, these results are similar to Saba et al. (1984), who observed that in natural populations of Culex sitiens the Amblyospora sp. infection rate did not show a significant correlation either with the water temperature or with the precipitation.

According to Issi (1986), who reviewed much of the data concerning the influence of environmental factors on host-parasite system for microsporidia, most studies have demonstrated that the temperature optimums for microsporidia and their hosts are similar and that temperature extremes are primarily deleterial to the development of the parasite. In most cases, development was determined by measuring the spore yield, and even though similar thermal optimum amplitudes are shared, the parasite is apparently more sensitive to extreme temperatures than the host. It is likely that the results were influenced by the host's behavior, which was opposite to the one described in the literature. Moreover, the temperature range was not as big as the one described as fundamental for interfering in the development of Amblyospora sp. e Polydispyrenia sp. Considering the data found in the literature, we can tell that the optimum temperature range in the Andorinhas river is between 21.0 and $23.0{ }^{\circ} \mathrm{C}$, where host population growths were recorded, as well as infection peaks of Amblyospora sp. and Polydispyrenia sp., with a prevalence of $2.33 \%$.

Therefore, it is acceptable to conclude that because of this being a high drainage-breeding site, this may have influenced the sampling of S. pertinax larvae because in the periods cited in the literature such as the population pool of the host, there was a decrease in the sampled larvae. The optimal temperature range observed for the parasite and host in this study is possibly influenced by peculiarities of the river. Therefore, other factors may have influenced the infections in S. pertinax by Amblyospora sp. and by Polydispyrenia sp., the water temperature in the Andorinhas river did not achieve the optimal temperature for spore production, neither did it achieve the deleterial temperatures cited in the literature. Because these intracellular parasites are so closely adapted to and dependent on their hosts, the influence of environmental factors therefore, is best considered as the influence on the host-parasite system.

Acknowledgments - This research was supported by (CAPES) Coordenação de Aperfeiçoamento de Pessoal de Nível Superior, and CNPq. We are grateful to Dr. Nicolau Maués da Serra Freire for the suggestions on statistical analyses and to Marcela Cristina da Silva Costa for help with field work and technical support.

\section{References}

ANDREADIS, TG., 1999. Epizootiology of Amblyospora stimuli (Microsporidia:Amblyosporidae) infection in field populations of a univoltine mosquito, Aedes stimulans (Diptera: Culicidae), inhabiting a temporary vernal pool. J. Invertebr. Pathol., vol. 74, no. 2, p. 198-205.
ARAÚJO-COUTINHO, CJPC., 1993. Abundância sazonal da população de formas imaturas de Simulium pertinax Kollar, 1832 (Diptera: Simuliidae) e da entomofauna associada, no município de Paraty, RJ. (Dissertação de Mestrado em Medicina Veterinária) - Universidade Federal Rural do Rio de Janeiro.

ARAÚJO-COUTINHO, CJPC., NASCIMENTO, ES., FIGUEIRÓ, R. and BECNEL, JJ., 2004. Seazonality and prevalence rates of microsporidia in Simulium pertinax (Diptera: Simuliidae) larvae in the region of Serra dos Órgãos, Rio de Janeiro, Brasil. J. Invertebr. Pathol., vol. 85, no. 3, p. 188-191.

BECNEL, JJ., 1997. Complementary techniques: Preparations of entomopathogens and diseased specimens for more detailed study using microscopy. Manual of Techniques in Insect Pathology. Ed. Lawrence A Lacey, Biological Techniques Series. Academic Press, London, p. 337-353.

BROOKS, WM. and CRANFORD, JD., 1972. Microsporidioses of the hymenopterous parasites, Campoletis sonorensis and Cardioehiles nigrieeps, larval parasites of Heliothis species. J. Invertebr. Pathol. vol. 20, no.1, p. 77-94.

CAMPOS, J. and ANDRADE, CFS., 2001. Considerações sobre os simulídeos (Diptera, Nematocera) e o seu controle. Entomol. $y$ Vect., vol. 8, no. 1, p. 27-50.

CANNING, EU. and HAZARD, EI., 1982. Genus Pleistophora Gurley, 1893: an assemblage of at least three genera. J. Protozool., vol. 29, no. 1, p. 39-49.

COSCARÓN, S., 1987. El Género Simulium Latreille en la Región Neotropical: Análisis de los Grupos Supreespecíficos. Especies que los Integran y Distribución Geográfica (Simuliidae, Diptera). Belém: Museu Paraense Emilio Goeldi.

CROSSKEY, RW., 1990. The Natural History of Blackflies. Ed. Wiley, West Sussex, England. 771p.

FAGER, EW., 1957. Determination and analysis of recurrent groups. Ecology, vol. 38, p. 586-595.

GARCIA, JJ., HAZARD, EI. and FUKUDA, T., 1989. Preliminary report of microsporidia in Simuliidae larvae from Argentina. J. Amer. Mosq. Control Assoc., vol. 5, no. 1, p. 64-69.

GERAIS, BB. and RIBEIRO, TC., 1986. Relatos de casos de Oncocercose: primeiro caso autóctone da região Centro-Oeste do Brasil. Rev. Soc. Br. Med. Trop., vol. 19, no. 2, p. 105-107.

HAZARD, EI. and OLDACRE, SW., 1975. Revision of Microsporidia (Protozoa) Close to Thelohania with Descriptions of One New Family, Eight New Genera, and Thirteen New Species. US Dept Agric Tech Bull 1530. p. 1-104.

ISSI, LV., 1986. Microsporidia as a phylum of parasitic protozoa. Acad. Sei. VSSR., (Leningrad) vol. 10, p. 6-136.

JOUVENAZ, DP. and LOFGREN, CS., 1984. Temperaturedependent spore dimorphism in Burenella dimorpha (Microspora: Microsporida). J. Protozool., vol. 31, no. 1, p. 175-177.

MADDOX, JV., 1987. Protozoan diseases. Epizootiology of Insect Diseases. Ed. JR Fuxa and Y Tanada, New York, John Wiley and Sons, p. 417-452.

MICIELI, MV., GARCIA, JJ. and ANDREADIS, TG., 2001. Epizootiological studies of Amblyospora albifasciati (Microsporidia: Amblyosporidae) in natural populations of Aedes albifasciatus (Diptera: Culicidae) and Mesocyclops 
annulatus (Copepoda: Cyclopidae) in a transient floodwater habitat. J. Invertebr. Pathol. vol. 77, no. 1, p. 68-74.

MORAES, MAP. and CHAVES, GM., 1974. Um caso de oncocercose no território de Roraima, Brasil. Rev. Inst. Med. Trop., São Paulo, vol. 16, no. 2, p. 110-113.

PETERSON, BV., 1956. Observations on the biology of Utha black flies (Diptera: Simuliidae). The Can. Entomol. LXXXVIII, p. 496-507.

SABA, DM., ODINDO, MO. and OTIENO, WA., 1984. Seazonal incidence of Amblyospora sp. (Thelohaniidae: Microsporidia) in Culex sitiens larvae at the Kenya coast. Insect. Sci. Appl., vol. 5, p. 269-272.

SEDLACEK, JD., DINTENFASS, LP., NORDIN, GL. and AJLAN, AA., 1985. Effects of temperature and dosage on Vairimorpha sp. 696 spore morphometrics, spore yield, and tissue specificity in Heliothis vireseens. J. Invertebr. Pathol., vol. 46 , no. 3, p. 320-324.

SERRA-FREIRE, NM., 2002. Planejamento e análise de pesquisas parasitológicas. Ed. Universidade Federal Fluminense, Niterói. 195p.
SHELLEY, AJ., 2002. Human onchocerciasis in Brazil: an overview. Cad. Saúde Pública, vol. 18, no. 5, p. 1167-1177.

SHELLEY, AJ., LOWRY CA., MAIA-HERZOG, M, LUNA DIAS, APA. and MORAES, MAP., 1997. Biosystematic studies on the Simuliidae (Diptera) of the Amazonia Onchocerciasis focus. Bull. Br. Mus. Nat. Hist. (Entomol.), vol. 66, no. 1, p. 1-120.

SWEENEY, AW. and BECNEL, JJ., 1991. Potential of Microsporidia for the Biological Control of Mosquitoes. Parasitol. Today, vol. 7, no. 8, p. 217-220.

THOMSON, HM., 1960. Variations of some of the characteristics used to distinguish between species of microsporidia spore size. J. Invertebr. Pathol., vol. 2, p. 147-151.

UNDEEN, AH., JOHNSON, MA. and BECNEL, JJ., 1993. The effects of temperature on the survival of Edhazardia-aedis (Microspora, Amblyosporidae), a pathogen of Aedes-aegypti. J. Invertebr. Pathol., vol. 61, no. 3, p. 303-307.

WEISER, J., 1991. Keys for identification of primary visible infections, biological control of vectors, manual for collecting field determination and handling of biofactors for control of vectors. W.H.O., New York. 189p. 